\title{
Determining the optimum percentages of fly ash, metakaolin and copper slag by replacing cement and fine aggregate in
}

m30 grade concrete.

\section{Determinación de los porcentajes óptimos de cenizas volantes, metacaolín y escoria de cobre mediante la sustitución de cemento y áridos finos en hormigón grado m30.}

\author{
Stephen Issac \\ Auckland University of Technology, Auckland, New Zealand. \\ email id: stephenissac992@gmail.com
}

\section{ABSTRACT}

The overall production of the cement has greatly increased which results lots of problems in environment as it involves the emission of $\mathrm{CO}_{2}$ gas. Environmental concerns, stemming from the high energy expense and carbon dioxide emission associated with cement manufacture have brought about pressures to reduce cement consumption through the use of supplementary materials. Materials such as Metakaolin, fly ash have good pozzolanic activity and are a good material for the production of high strength concrete. Copper slag is a by-product of copper extraction by smelting. Copper slag can be used in concrete production as a partial replacement for sand. However, it is expected that the use of Metakaolin, Fly ash and Copper slag in concrete improves the strength properties of concrete.

Keywords: Supplementary cementitious material, cement, fine aggregate.

\section{RESUMEN}

La producción general de cemento ha aumentado considerablemente, lo que genera muchos problemas en el medio ambiente, ya que implica la emisión de gas CO2. Las preocupaciones ambientales, derivadas del alto gasto energético y la emisión de dióxido de carbono asociados con la fabricación de cemento, han generado presiones para reducir el consumo de cemento mediante el uso de materiales complementarios. Materiales como el metacaolín, las cenizas volantes tienen una buena actividad puzolánica y son un buen material para la producción de hormigón de alta resistencia. La escoria de cobre es un subproducto de la extracción de cobre por fundición. La escoria de cobre se puede utilizar en la producción de hormigón como reemplazo parcial de la arena. Sin embargo, se espera que el uso de metacaolín, cenizas volantes y escoria de cobre en el hormigón mejore las propiedades de resistencia del hormigón. 
Sustainability, Agri, Food and Environmental Research, (ISSN: 0719-3726), 10(X), 2022: http://dx.doi.org/

Palabras clave: Material cementante suplementario, cemento, agregado fino.

\section{INTRODUCTION}

Concrete means a mixture of a binding material, aggregates as filler materials and water. The cement concrete is a mixture of cement, sand, pebbles or crushed rocks and water. The cement concrete has attained the status of a major building material in the modern construction. Although Portland cement demands are decreasing in industrial nations, it is increasing dramatically in developing countries. Cement demand projections shows that by the year 2050 it will reach 6000 million tons. Portland cement production leads to major $\mathrm{CO}_{2}$ emissions accounting for almost 0.7 tons of $\mathrm{CO}_{2}$ per ton of cement, which represents almost $7 \%$ of the total $\mathrm{CO}_{2}$ world emissions. Not only $\mathrm{CO}_{2}$ releases from cement manufacture but also $\mathrm{SO}_{3}$ and $\mathrm{NO}_{3}$ which can cause the greenhouse effect and acid rain. Since Portland cement is used mostly in concrete production, the most important building material on Earth, partial replacement by pozzolanic by-products and mineral additions will allow relevant carbon dioxide emission reductions.

Supplementary cementitious materials (SCM) are finely ground solid materials that are used to replace a portion of the cement in a concrete mixture. The supplementary cementitious materials may be naturally occurring or man-made waste. Various types of pozzolanic materials that improve cement properties have been used in cement industry for a long time such as Metakaolin and fly ash. Metakaolin possesses a high reactivity with calcium hydroxide having the ability to accelerate cement hydration. Since current concrete structures present higher permeability levels that allow aggressive elements to enter, leading corrosion problems, using pozzolanic admixtures not only reduce carbon dioxide emissions but also allow structures with longer service life, thus lowering their environmental impact (Bhaskara Teja Chavali and Perla Karunakar;2016) . Fly Ash is one of the major waste materials available from thermal power plants and its treatment and disposal was a problem in the early stages. When fly ash is replaced with $\mathrm{OPC}$, it reacts with the calcium to form the calcium silicate hydrate $(\mathrm{C}-\mathrm{S}-\mathrm{H}$ ) gel (Arka Saha et.al;2014). From previous works it is evident that they are very effective pozzolanic materials and effectively enhances the strength parameters of concrete.

Copper slag is a non ferrous slag obtained as a by-product during the matte (molten copper sulphide) smelting and refining of copper. Major constituents of a smelting charge are sulphides and oxides of iron and copper. As a result, copper-rich matte (sulphides) and copper slag (oxides) are formed as two separate liquid phases. The molten slag is discharged from the furnace at $1000-1300^{\circ} \mathrm{C}$ (Ambily P.S et.al;2015). When liquid slag is cooled slowly, it forms a dense, hard crystalline product where a quick solidification by pouring molten slag into water provides amorphous granulated slag. Recycling, recovering of metal, production of value added products and disposal in slag dumps or stockpiles are 
Sustainability, Agri, Food and Environmental Research, (ISSN: 0719-3726), 10(X), 2022: http://dx.doi.org/

the options for management of copper slag. It has been widely used for abrasive tools, roofing granules, cutting tools, abrasive, tiles, glass, road-base construction, railroad ballast, asphalt pavements, cement clinker and blended cement production. Fine or coarse aggregate in the preparation of cement mortar Copper slag has been excluded from the listed hazardous waste category of the United States Environmental Protection Agency (USEPA). The United Nations (UN) Basel Convention on the Trans boundary Movement of Hazardous Waste and its Disposal also ruled that copper slag is not a hazardous waste. The slag was made of black glassy particles and granular in nature and has a particle size range similar to sand. At present about 33 million tons of copper slag is generating annually worldwide among that India contributing 6 to 6.5 million tones.

\section{MATERIALS AND METHODS}

The materials used in the experimental study are, Cement (OPC53), fly ash and metakaolin as cement replacement material, copper slag as fine aggregate replacement material and Superplasticizer.

\section{A. Cement}

In the present experimental work, Ordinary Portland cement of Grade 53 was used grade confirming to IS $12269: 1987$. Cement is generally used as the main binder material.

\section{B. Fine Aggregate}

Fine aggregates usually consist of river sand. Owing to the scarcity of river sand and the environmental impact of river excavations, m-sand was used as the fine aggregate in the present study. M-sand used was confirming to Zone II of IS 383:1970 (Reaffirmed 2016).

\section{Coarse Aggregate}

The coarse aggregates are generally crushed stones with size ranging from 20 $\mathrm{mm}$ to $4.75 \mathrm{~mm}$. They occupy around 35 to $70 \%$ of the total volume of concrete. The coarse aggregates used were with a nominal size of $20 \mathrm{~mm}$ downgraded crushed granite aggregates. The properties of coarse aggregates were confirming to IS 383:1970 (Reaffirmed 2016).

D. Fly ash

Fly ash is an industrial waste product which is accepted as an environmental pollutant, generated during the combustion of coal for energy production. It can be used as admixtures or as replacement of cement. 
Sustainability, Agri, Food and Environmental Research, (ISSN: 0719-3726), 10(X), 2022:

http://dx.doi.org/

\section{E. Metakaolin}

Metakaolin is artificially manufactured pozzolanic additive. Chemical formula of metakaolin is $\mathrm{Al}_{2} \mathrm{O}_{3} \cdot 2 \mathrm{SiO}_{2}$, a dehydroxylated aluminium silicate. It is the dehydroxylated form of the clay mineral kaolinite. Rocks that are rich in kaolinite are known as china clay or kaolin, traditionally used in the manufacture of porcelain.

\section{F. Copper slag}

Copper slag is a non ferrous slag obtained as a by-product during the matte (molten copper sulphide) smelting and refining of copper. Major constituents of a smelting charge are sulphides and oxides of iron and copper.

\section{G. Superplasticizer}

To improve the workability of concrete Superplasticizer is used. It is an admixture of a new generation based on modified polycarboxylic ether. It is free of chloride and low alkali. It is compatible with all types of cements. The product has been primarily developed for applications in high performance concrete where the highest durability and performance is required. Optimum dosage should be determined with trial mixes, dosage range of 500 $\mathrm{ml}$ to $1500 \mathrm{ml}$ per $100 \mathrm{~kg}$ of cementitious material is normally recommended. Because of variations in concrete materials, job site conditions, and/or applications, dosages outside of the recommended range may be required.

\section{EXPERIMENTAL STUDY}

The compressive strength test and split tensile strength test were done to determine the optimum values of each material.

\section{A. Compressive Strength Test}

The compressive strength of concrete was assessed by crushing to destruction of the test cubes by means of compression testing machine according to IS 516:1959 (Reaffirmed 2013). Cubes of $150 \mathrm{~mm}$ size were used for the testing. Load at the failure divided by area of specimen gives the compressive strength of concrete.

$$
\text { Compressive strength }=\frac{\text { Load applied }}{\text { Cross sectional area }}-[\text { eq. (1)] }
$$

1) Compressive strength of conventional M30 concrete.

The 7th day and 28th day compressive strength values of normal concrete mix is given in Table below. 
Sustainability, Agri, Food and Environmental Research, (ISSN: 0719-3726), 10(X), 2022: http://dx.doi.org/

Table. 1 Compressive strength of conventional M30 concrete

\begin{tabular}{ccc} 
Mix designation & $\begin{array}{c}7^{\text {th }} \text { day compressive strength } \\
\left(\mathrm{N} / \mathrm{mm}^{2}\right)\end{array}$ & $\begin{array}{c}28^{\text {th }} \text { day compressive } \\
\text { strength }\left(\mathrm{N} / \mathrm{mm}^{2}\right)\end{array}$ \\
\hline $\mathrm{M3O}_{1}$ & 27.58 & 41.04 \\
$\mathrm{M3O}_{2}$ & 27.43 & 42.18 \\
$\mathrm{M3O}_{3}$ & 27.10 & 40.16 \\
Average value & 27.37 & 41.12
\end{tabular}

2) Compressive strength of fly ash blended M30 concrete.

The 7th day and 28th day compressive strength values of fly ash blended concrete mix is given in Table below.

Table. 2 Compressive strength of fly ash blended M30 concrete

\begin{tabular}{ccc} 
Mix designation & $\begin{array}{c}7^{\text {th }} \text { day compressive } \\
\text { strength }\left(\mathrm{N} / \mathrm{mm}^{2}\right)\end{array}$ & $\begin{array}{c}28^{\text {th }} \text { day compressive } \\
\text { strength }\left(\mathrm{N} / \mathrm{mm}^{2}\right)\end{array}$ \\
\hline $\begin{array}{c}\text { M30 } \\
\text { F M30 (08\% Fly } \\
\text { ash) }\end{array}$ & 27.37 & 41.12 \\
F $_{2}$ M30 (10\% Fly \\
ash) \\
$\begin{array}{c}\text { F3 } 30 \text { (12\% Fly } \\
\text { ash) }\end{array}$
\end{tabular}

The partial replacement of cement by fly ash increased the compressive strength in all the considered cases and the maximum strength was obtained for $10 \%$ fly ash replacement at which the $28^{\text {th }}$ day compressive strength. There is an increase of $16 \%$ from the value of control mix and the optimum value of fly ash blended concrete. There is a significant improvement in the compressive strength of the concrete as because of the pozzolanic nature of fly ash and its void filling ability (Ogale R.A and Snehal S.Shinde;2016) .

3) Compressive strength of fly ash-metakaolin blended M30 concrete

The 7th day and 28th day compressive strength values of fly ash-metakaolin blended concrete mix is given in Table 3. In fly ash-metakaolin blended concrete of M30 grade, optimum percentage of fly ash is replaced with 10,15 and $20 \%$ of metakaolin and the results obtained on the $7^{\text {th }}$ day and $28^{\text {th }}$ day are as follows 
Sustainability, Agri, Food and Environmental Research, (ISSN: 0719-3726), 10(X), 2022: http://dx.doi.org/

Table. 3 Compressive strength of fly ash-metakaolin blended M30 concrete

\begin{tabular}{ccc} 
Mix designation & $\begin{array}{c}7^{\text {th }} \text { day compressive } \\
\text { strength }\left(\mathrm{N} / \mathrm{mm}^{2}\right)\end{array}$ & $\begin{array}{c}28^{\text {th }} \text { day compressive strength } \\
\left(\mathrm{N} / \mathrm{mm}^{2}\right)\end{array}$ \\
\hline M30 & 27.37 & 41.12 \\
$\mathrm{~F}_{2} \mathrm{MK}_{10} \mathrm{M} 30$ & 36.28 & 44.87 \\
$\mathrm{~F}_{2} \mathrm{MK}_{15} \mathrm{M} 30$ & 41.95 & 46.62 \\
$\mathrm{~F}_{2} \mathrm{MK}_{20} \mathrm{M} 30$ & 41.79 & 45.41
\end{tabular}

The replacement of fly ash with Metakaolin increased the compressive strength in all the considered cases and the maximum strength was obtained for $15 \%$ metakaolin replacement at which the $28^{\text {th }}$ day compressive strength. There is an increase of $13.35 \%$ from the value of control mix and the optimum value of fly ash metakaolin blended concrete. The increase in the compressive strength could be due to the pozzolanic, void filling and cement hydration acceleration mechanisms of metakaolin by which the microstructure of fly ash-metakaolin blended concrete became more compact and denser [12].

4) Compressive strength of copper slag blended M30 concrete.

The 7th day and 28th day compressive strength values of copper slag blended concrete mix is given in Table 4. In the copper slag blended concrete of M30 grade, fine aggregate is replaced by copper slag with $30 \%, 40 \%$ and $50 \%$. The obtained results on the $7^{\text {th }}$ day and $28^{\text {th }}$ day are as follows:

Table. 4 Compressive strength of copper slag blended M30 concrete

\begin{tabular}{ccc} 
Mix designation & $\begin{array}{c}7^{\text {th }} \text { day compressive } \\
\text { strength }\left(\mathrm{N} / \mathrm{mm}^{2}\right)\end{array}$ & $\begin{array}{c}28^{\text {th }} \text { day compressive } \\
\text { strength }\left(\mathrm{N} / \mathrm{mm}^{2}\right)\end{array}$ \\
\hline M30 & 27.37 & 41.12 \\
CS $_{30}$ M30 & 30.29 & 40.82 \\
CS $_{40}$ M30 & 34.24 & 45.94 \\
CS $_{50}$ M30 & 32.08 & 42.02
\end{tabular}

The compressive strength development of concrete containing different percent replacement of copper slag was conducted. According to the results obtained the compressive strength increased by using copper slag as fine aggregate replacing material. Due to the higher value of specific gravity its packing is more compact and also provides a better packing, leads to production of most efficient mix, the contents of cement, water, 
Sustainability, Agri, Food and Environmental Research, (ISSN: 0719-3726), 10(X), 2022:

http://dx.doi.org/

and coarse aggregate were kept constant while the percentages of copper slag as a replacement for fine aggregate varied from 30 to $50 \%$. Results showed that replacement of $40 \%$ of fine aggregate with copper slag caused major changes on concrete strength, the strength increase about $11.72 \%$.

\section{B. Split Tensile Strength Test}

The split tensile test was carried out as per IS 5816: 1999 (Reaffirmed 2008) by placing the cylindrical specimen horizontally between the loading surfaces of compression testing machine and then load was applied until the failure of the cylinder along the vertical diameter. This is an indirect method for determining the tensile strength of concrete. Cylindrical specimens of diameter $150 \mathrm{~mm}$ and height $300 \mathrm{~mm}$ were used for this test. The split tensile strength was calculated by,

$$
\text { Tensile strength }=\frac{2 \mathrm{P}}{\pi \mathrm{DL}}-[\text { eq. (2)] }
$$

Where,

$\mathrm{P}=$ applied load

$\mathrm{D}=$ diameter of the cylinder

$\mathrm{L}=$ length of the cylinder

The split tensile strength of concrete mixes was found using compression testing machine.

1) Split tensile strength of conventional M30 concrete.

The 7th day and 28th day split tensile strength values of normal concrete mix is given in Table below.

Table. 5 Split tensile strength of conventional M30 concrete

\begin{tabular}{ccc} 
Mix designation & $\begin{array}{c}7^{\text {th }} \text { day Split tensile } \\
\text { strength } \\
\left(\mathrm{N} / \mathrm{mm}^{2}\right)\end{array}$ & $\begin{array}{c}28^{\text {th }} \\
\text { strength }\left(\mathrm{N} / \mathrm{mm}^{2}\right)\end{array}$ \\
\hline${\mathrm{M} 30_{1}}_{\mathrm{M} 30_{2}}$ & 2.44 & 3.30 \\
$\mathrm{M} 30_{3}$ & 2.46 & 3.33 \\
Average value & 2.40 & 3.31 \\
& 2.43 & 3.313
\end{tabular}

2) Split Tensile strength of fly ash blended M30 concrete. 
The 7th day and 28th day Split Tensile strength values of fly ash blended concrete mix is given in Table 6 . In the fly ash blended M30 grade concrete, 8, 10 and 12\% replacement of cement with fly ash is done and the split tensile values obtained on the $7^{\text {th }}$ day and $28^{\text {th }}$ day are as follows:

Table. 6 Split Tensile strength of fly ash blended M30 concrete

\begin{tabular}{ccc} 
Mix designation & $\begin{array}{c}7^{\text {th }} \text { day split tensile } \\
\text { strength }\left(\mathrm{N} / \mathrm{mm}^{2}\right)\end{array}$ & $\begin{array}{c}28^{\text {th }} \text { day split Tensile } \\
\text { strength }\left(\mathrm{N} / \mathrm{mm}^{2}\right)\end{array}$ \\
\hline $\begin{array}{c}\text { M30 } \\
\text { F1M30 (08\% Fly } \\
\text { ash) }\end{array}$ & 2.43 & 3.31 \\
F $_{2}$ M30 (10\% Fly & 2.47 & 3.35 \\
ash) & 2.51 & 3.42 \\
F $_{3}$ M30 (12\% Fly & & 3.29 \\
ash)
\end{tabular}

The partial replacement of cement by fly ash increased the split tensile strength in all the considered cases and the maximum strength was obtained for $10 \%$ fly ash replacement at which the $28^{\text {th }}$ day compressive strength. There is an increase of strength from the value of control mix and the optimum value of fly ash blended concrete. There is a significant improvement in the split tensile strength of the concrete as because of the pozzolanic nature of fly ash and its void filling ability.

3) Split Tensile strength of fly ash-metakaolin blended M30 concrete

The 7 th day and 28th day split tensile strength values of fly ash-metakaolin blended concrete mix are given in Table 7. In the fly ash-metakaolin blended M30 grade concrete, optimum percentage of fly ash is replaced with 10,15 and $20 \%$ of metakaolin and the split tensile strength results obtained on the $7^{\text {th }}$ day and $28^{\text {th }}$ day are as follows:

Table. 7 Split tensile strength of fly ash-metakaolin blended M30 concrete

\begin{tabular}{ccc} 
Mix designation & $\begin{array}{c}7^{\text {th }} \text { day split tensile } \\
\text { strength }\left(\mathrm{N} / \mathrm{mm}^{2}\right)\end{array}$ & $\begin{array}{c}28^{\text {th }} \text { day split tensile strength } \\
\left(\mathrm{N} / \mathrm{mm}^{2}\right)\end{array}$ \\
\hline M30 & 2.43 & 3.31 \\
$\mathrm{~F}_{2} \mathrm{MK}_{10} \mathrm{M} 30$ & 2.53 & 3.48 \\
$\mathrm{~F}_{2} \mathrm{MK}_{15} \mathrm{M} 30$ & 2.55 & 3.51 \\
$\mathrm{~F}_{2} \mathrm{MK}_{20} \mathrm{M} 30$ & 2.51 & 3.45
\end{tabular}


The replacement of fly ash with Metakaolin increased the split tensile strength in all the considered cases and the maximum strength was obtained for $15 \%$ metakaolin replacement at which the $28^{\text {th }}$ day compressive strength. There is an increase of strength from the value of control mix and the optimum value of fly ash metakaolin blended concrete. The increase in the strength could be due to the pozzolanic, void filling and cement hydration acceleration mechanisms of metakaolin by which the microstructure of fly ash-metakaolin blended concrete became more compact and denser.

4) Split tensile strength of copper slag blended M30 concrete.

The 7th day and 28th day split tensile strength values of copper slag blended concrete mix is given in Table 8 . In the copper slag blended M30 grade concrete, fine aggregate is replaced by copper slag with $30 \%, 40 \%$ and $50 \%$. The obtained split tensile strength results on the $7^{\text {th }}$ day and $28^{\text {th }}$ day are as follows:

Table. 8 Split tensile strength of copper slag blended M30 concrete

\begin{tabular}{ccc} 
Mix designation & $\begin{array}{c}7^{\text {th }} \text { day split tensile } \\
\text { strength }\left(\mathrm{N} / \mathrm{mm}^{2}\right)\end{array}$ & $\begin{array}{c}28^{\text {th }} \text { day split tensile strength } \\
\left(\mathrm{N} / \mathrm{mm}^{2}\right)\end{array}$ \\
\hline M30 & 2.43 & 3.31 \\
$\mathrm{CS}_{30} \mathrm{M} 30$ & 2.41 & 3.28 \\
$\mathrm{CS}_{40} \mathrm{M} 30$ & 2.45 & 3.33 \\
$\mathrm{CS}$ & 2.43 & 3.30
\end{tabular}

The split tensile strength development of concrete containing different percent replacement of copper slag was conducted. According to the results obtained the split tensile strength slightly increased by using copper slag as fine aggregate replacing material than the control mix. Due to the higher value of specific gravity its packing is more compact and also provides a better packing, leads to production of most efficient mix, the contents of cement, water, and coarse aggregate were kept constant while the percentages of copper slag as a replacement for fine aggregate varied from 30 to $50 \%$. Results showed that replacement of $40 \%$ of fine aggregate with copper slag caused changes on concrete strength.

\section{RESULTS AND CONCLUSION}

Experimental study on the effect of alternative materials such as fly ash, metakaolin and copper slag in the concrete was conducted. The fly ash replacement in concrete was done as $8 \%, 10 \%$ and $12 \%$ for cement by weight. The optimum of fly ash was replaced 
Sustainability, Agri, Food and Environmental Research, (ISSN: 0719-3726), 10(X), 2022: http://dx.doi.org/

by Metakaolin from $10 \%, 15 \%$ and $20 \%$. The fine aggregate was replaced by copper slag from 30,40 and $50 \%$ in the concrete. The optimum percentage of fly ash was $10 \%$ when replaced with cement. The optimum percentage obtained for Metakaolin when replaced for the optimum percentage of fly ash was $15 \%$. For copper slag when replaced to fine aggregate the optimum percentage obtained was $40 \%$.

The compressive strength of the modified mixes was more than that of the normal mix. When the normal mix concrete is re-designed with alternative materials, for each replacement levels the strength characteristics was improved. The split tensile strength was also improved to an extent. Concerning the split tensile strength, the least strength was obtained when replaced with copper slag with fine aggregate. Apart from that the modified mix shows better results in case of compressive as well as the split tensile strength. The increase in the strength characteristic when alternative materials were used may because of the properties of fly ash, metakaolin and copper slag such as the pozzolanic nature, void filling and the cement hydration acceleration mechanism of fly ash and Metakaolin and the higher value of specific gravity of copper slag which makes the packing more compact to get efficient concrete mix

\section{REFERENCES}

Ambily P.S ,Umarani C, Ravisankar K, Prabhat Ranjan Prem, Bharatkumar B.H, Nagesh R. Iyer (2015) Studies on ultra high performance concrete incorporating copper slag as fine aggregate, Construction and Building Materials, 77, 233-240

Arka Saha, Samaresh Pan, Soumen Pan (2014) Strength development characteristics of high strength concrete incorporating an Indian fly ash, International Journal of Technology Enhancements and Emerging Engineering Research, 2, 101-107

Barbhuiya S, Chow P (2015) Microstructure, hydration and nanomechanical properties of concrete containing metakaolin, Construction and Building Materials, 95, 696702

Bhaskara Teja Chavali, Perla Karunakar (2016) Effect of Varying Quantities of Metakaolin and Fly Ash on Strength Characteristics of Concrete, International Journal For Technological Research In Engineering, 4, 282-288

Caijun Shi, Christian Meyer, Ali Behnood (2008) Utilization of copper slag in cement and concrete, Resources Conservation and Recycling, 52, 1115-1120

Erhan Guneyisi , Mehmet Gesoglu , Zeynep Algın , Kasım Mermerdas (2014), Optimization of concrete mixture with hybrid blends of metakaolin and fly ash using response surface method, Composites: Part B, 60, 707-715 
Sustainability, Agri, Food and Environmental Research, (ISSN: 0719-3726), 10(X), 2022:

http://dx.doi.org/

Guneyisi E., Gesoglu M. (2014) Combined effect of steel fiber and metakaolin incorporation on mechanical properties of concrete, Composites, 27, 83-91

Hossam S, Hassan A. (2016) Time-dependence of chloride diffusion for concrete containing metakaolin, Building Engineering, 7, 159-169

Kelestemur O, Demirel B. (2012) Effect of metakaolin on the corrosion resistance of structural lightweight concrete, Construction and Building Materials, 81, 172-178

Mermerdas K., Gesoglu M. (2012) Strength development of concretes incorporated with metakaolin and different types of calcinedkaolins, Construction and Building Materials, 37, 766-774

Mirmoghtadaei R., Mohammadi M. (2015) The impact of surface preparation on the bond strength of repaired concrete bymetakaolin containing concrete, Construction and Building Materials, 80, 76-83

Narmatha M, Felixkala T (2016) Metakaolin and fly ash with partial replacement of cement using In HPC, International Journal of Civil and Structural Engineering Research, 4, Pp 101-106

Nova John (2013) Strength Properties of Metakaolin Admixed Concrete, International Journal of Scientific and Research Publications, 3, 1-7

Ogale R.A, Snehal S.Shinde (2016) Effect of Metakaolin and Fly ash on Strength of Concrete, International Journal of Advanced Research in Science Management and Technology, 2, 1-5

Padhye R. D, Deo.S (2016) Cement replacement by fly ash in concrete, International Journal of Engineering Research, 5, 60-62

Received: $30^{\text {th }}$ January 2021; Accepted: $14^{\text {th }}$ March 2021; First distribution: 01th April 2021 